\title{
Reproductive parameters of primiparous Awassi sheep and mortality rates of their lambs in steppe climates
}

\author{
Ş. İnal ${ }^{1}$, B. Coşkun², D.A. Dinç ${ }^{3}$, M. Çam ${ }^{1 *}$
}

${ }^{1}$ Department of Animal Science; ${ }^{3}$ Department of Obstetrics and Gynecology, Faculty of Veterinary Medicine, Selçuk University, 42003; ${ }^{2}$ Konya Food and Agricultural University, Faculty of Agriculture and Natural Sciences, 42080, Turkey

Corresponding author e-mail- *mustafa.cam@selcuk.edu.tr

Journal of Livestock Science (ISSN online 2277-6214) 12: 262-267

Received on 4/6/21; Accepted on25/7/21; Published on $8 / 8 / 21$

doi. 10.33259/JLivestSci.2021.262-267

\begin{abstract}
This study was aimed to investigate reproductive parameters, birth weight, weaning weight and survival rates of primiparousAwassi sheep, done by hand-mated, which were transferred from Ceylanpınar Agricultural Enterprise to İlciÇiçekdağı Agricultural Enterprise where the climate is colder than Ceylanpınar, has arid and hot climate conditions, also to check their adaptation and productivity in colder climates. The reproductive data was obtained from 985 primiparousAwassi yearling lambs, done controlled mating with 35 rams. The birth weight of newborn lambs was recorded and then the study was terminated with calculating weaning weight of the lambs.Estrousandlambing rate, litter sizewere calculated as 96.45\%, 90.55\%, 1.09 respectively. Twinning rate was found as $9.08 \%$. Even though stillbirths were $0.12 \%$ for single lambs and $3.09 \%$ for twin lambs; mortality rate of lambs until weaning was found as $22.57 \%$ for single lambs and $20.57 \%$ for twin lambs. Lamb birth and weaning weights were determined as 4.75 and $29.52 \mathrm{~kg}$ for single lambs; 3.82 and $28.80 \mathrm{~kg}$ for twin lambs; 4.19 and $28.44 \mathrm{~kg}$ for females; 4.38 and $29.88 \mathrm{~kg}$ for males. Reproductive parameters of Awassi sheep raised in the unusual climate conditions such as rainy and cold weatherwere not affected as much as expected. Satisfactory results were obtained from the study regarding to reproductive parameters in different climates despite some management problems affecting lamb mortality rate. Genotypes and preservation of Awassi population in Ceylanpınar Agricultural Enterprise are said to be really in good conditions.
\end{abstract}

Keywords: Awassi sheep; reproductive parameters; climate conditions; steppe;mortality 


\section{Introduction}

In obtaining meat, milk, wool and manure, sheep breeding is important for livestock production. Reproductive performance is one of the most important traits for sheep breeding which maintains the stability of replacement rate, accelerating genetic improvement by increasing efficiency of selection and culling. For this purpose, improving reproductive performance of sheep needs to be taken into consideration.

It's known that most of the total sheep population is native breeds in Turkey. Awassi is one of these native breeds located in South-eastern Anatolia which has a semi-arid climate with very hot, dry summers and cold, often snowy winters. Awassi is durable to harsh environments and able to produce milk in hot temperatures. Awassi rams proved to show good reproductive performance in high temperatures.

Even though Awassi sheep are used to being raised in semi-desert regions, the fact that it was imported by more than 30 countries proved that they had adapted well and caused high genetic variation among flocks(Mahmoud, 2015). Awassi is known to be improver breed in the crossbreeds of other fat tailed sheep breeds adapted to steppe climate(Galal et al., 2008). Moreover, the reproductive performance of Turkish Awassi strain had desirable effects when crossed with different strains(Haile et al., 2019). It is known that young animals showed better adaptation in harsh climates (Renaudeau et al., 2012) and reproductive parameters were stress indicators of climate for ewes (Dobson et al., 2012). Üstüner and Oğan (2013) investigated the reproductive capacity of Awassi ewes and survival rates of their lambs in the Central Anatolia. They found that the productivity and reproductive performance would get better by increasing parity. To get more accurate results, the adaptation capacity of young Awassi ewes in steppe climates by checking reproductive parameters should be taken into consideration by analysing high amount of data. So the purpose of this study was to check reproductive performance and productivity of primiparous Awassi sheep in colder climate.

\section{Materials and Methods}

The study was carried out at IlciCicekdagi Agriculture Center $\left(39^{\circ} .37^{\prime} \mathrm{N} ; 34^{\circ} .24^{\prime} \mathrm{E}\right)$, where steppe climate existed. The average temperature of this area was $11.6^{\circ} \mathrm{C}$ monthly which dropped below zero during most of the days in winter. The average annual precipitation was $368 \mathrm{~mm}$. The animals were transported from Ceylanpınar Agriculture Center $\left(36^{\circ} .50^{\prime} \mathrm{N} ; 3^{\circ} .55^{\prime} \mathrm{E}\right)$ where the climate was semi-arid with $17.6^{\circ} \mathrm{C}$ of monthly temperature and $379 \mathrm{~mm}$ of annual precipitation. The ethical standards of the study were approved by Selçuk University Experimental Research and Application Centre, Animal Experiments Ethics Committee - 2019/14 Number Ethics Committee Decision.

The yearlings were kept outdoor pastures in whole summer and most of the spring and early autumn periods. After mating period, the ewes were kept semi open sheep shed with $30 \times 80 \mathrm{~m}$ dimension for indoor and $60 \times 80 \mathrm{~m}$ dimension foroutdoor area. 1000 female, 25 male yearling lambs with 1.5 years age and 10 mature rams were used in this study. Fifteen females and one male yearling lambs were excluded from the study because of predator attacks, diseases (Coenuruscerebralis) and sending to slaughterhouse during the mating season. Even though the mating season of Awassi ewes normally takes place between late June and early September to lamb between November-February (Zarkawi, 1997); the mating of sheep was done by hand-mated between 24th October and 31st December to avoid births in winter. Oestrus was detected by teaser rams every morning. Then controlled mating was carried out to those showing oestrus with the chosen ram. If they still showed oestrus at the next teasing, they would be remated again. The ewes were fed with extra 200-300 g concentrate feed while the rams were fed with $1 \mathrm{~kg}$ barley and $150 \mathrm{~g}$ soybean supplemented with carrot ( 50-100 g), raisins $(\sim 15-20 \mathrm{~g})$, vitamins $(\sim 5 \mathrm{~g})$ and roughage feed $(\sim 200 \mathrm{~g})$ during the flushing period between $1 \mathrm{st}$ and 30 th October. All the sheep were offered freshwater and mineral rocks ad libitum.

Births occurred between 20th March and 1st June. Newborn lambs were cleaned, dried, weighed and identified by ear tags. And then their birth weight, birth type and sex were recorded except birth weight of stillbirths. The lambs were stayed at portable individual pens with their mothers up to first day of their age. After having been given colostrum individually with bottle for 3 days, lambs had a group feeding using a bucket with 5-6 artificial nipples. The experiment was terminated when the weaning weight of lambs was recorded.

The parameters in this study were calculated by using theseformulas; Oestrus rate (number of ewes showed oestrus/total number of ewes $\times 100$ ), Infertility rate (number of ewes showed anoestrus/total number of ewes $\times 100$ ), lambing rate (number of ewes lambing/total number of ewes $\times 100$ ), litter size (number of lambs born / number of ewes lambing), Twinning rate (number of twin lambing/total lambing $\times 100$ ), stillbirth rate (number of death lambs in the $24 \mathrm{~h}$ of postpartum period/number of lambing).

Statistical analyses

Sixty-five lambs withdata errors or missing data were excluded from the study as well as the number of stillbirth lambs while analysing of lamb weaning weight. Descriptive analysis was performed to determine reproductive parameters concerning the rate of prolificacy, litter size, infertility, stillbirth and lamb survival by using Excel software program. Lamb birth and weaning weight were analysed by the GLM procedure at SPSS (ver. 22.0). Sex and type of birth were included to the model as fixed effect. When analysed for weaning weight, 
birth weight and age of lambs were determined as covariate. The model was set $\mathrm{p}<0.05$ to determine significant differences between groups.

\section{Results}

At the end of mating season, 950 of $985(96.45 \%)$ yearling lambs showed oestrus and mated with rams. 35 yearling lambs neither showed oestrus nor accepted rams for mating were defined as infertile (3.55\%). 893 of 985 yearling lambs mating with rams were able to lamb, which meant $90.55 \%$ of lambing rate. Total 81 twining lambing were recorded with 9.08 twining rate. Totally, 973 lambs were obtained in the season so one could say that the litter size was found to be 1.09 .

Thirty two out of 34 breeding rams $(94.12 \%)$ used in this study were able to mate with the ewes. The average number of ewes mated to the ram was 29.7 and maximum number was 75 . The fertility rate of rams was between $27.78 \%$ and $100 \%$.

After lambing, stillbirth rate was found to be $0.12 \%$ for single births and $3.09 \%$ for twin births. Preweaning period lasted about 119 days. After that the lambs were weighed to calculate the weaning weight which was found to be $29.16 \mathrm{~kg}$.Lamb birth, weaning weight and mortality rate were illustrated in Table 2. Birth weight was affected significantly by both sex $(\mathrm{p}<0.01)$ and type of birth $(\mathrm{p}<0.001)$ while weaning weightwasn't affected significantly by those.Significant interaction was reported between type of birth and sex for lamb birth weight $(\mathrm{p}<0.05)$ while there wasn't any interaction between those for weaning weight of the lambs. Generally, male newborn lambs were heavier than female lambs. Single new born lambs were also heavier than twins either. Mortality rate of lambs in preweaning period wasn't influenced by either type of birth or sex.

Table 1.The parameters of primiparousAwassi ewes and their lambs.

\begin{tabular}{|c|c|}
\hline Total number of ewes for mating & 985 \\
\hline Number of ewes showed oestrus & 950 \\
\hline Oestrus rate & $96.45 \%$ \\
\hline Infertility rate & $3.55 \%$ \\
\hline Number of lambing ewes & 893 \\
\hline Lambing rate & $90.55 \%$ \\
\hline Number of twin lambing & 81 \\
\hline Twinning Rate & $9.08 \%$ \\
\hline Number of lambs born & 973 \\
\hline Litter size & 1.09 \\
\hline
\end{tabular}

Table 2. Birth, weaning weight $(\mathrm{kg})$ and mortality rate of lambs of primiparous Awassi ewes according to type of birth and sex.

\begin{tabular}{|c|c|c|c|c|c|c|}
\hline \multirow[b]{2}{*}{ Birth Type } & \multirow[b]{2}{*}{ Sex } & \multicolumn{2}{|c|}{ Birth Weight $^{1}(\mathrm{~kg})$} & \multicolumn{2}{|c|}{ Weaning Weight $(\mathrm{kg})$} & \multirow{2}{*}{$\frac{\text { Mortality Rate }}{\%}$} \\
\hline & & $\mathrm{N}$ & $\mathrm{x} \pm \mathrm{Sx}$ & $\mathrm{N}$ & $\mathrm{x} \pm \mathrm{Sx}$ & \\
\hline \multirow[t]{2}{*}{ Single } & Male & 433 & $4.90 \pm 0.04 *$ & 337 & $30.23 \pm 0,62$ & 23.23 \\
\hline & Female & 377 & $4.59 \pm 0.04 *$ & 301 & $28.80 \pm 0,64$ & 21.82 \\
\hline \multirow[t]{2}{*}{ Twin } & Male & 78 & $3.94 \pm 0.09$ & 57 & $29.52 \pm 1,51$ & 20.83 \\
\hline & Female & 79 & $3.91 \pm 0.09$ & 55 & $28.09 \pm 1.55$ & 20.29 \\
\hline Single & & 810 & $4.75 \pm 0.03 * * *$ & 638 & $29.52 \pm 0,44$ & 22.57 \\
\hline Twin & & 157 & $3.92 \pm 0.06 * * *$ & 112 & $28.80 \pm 1.12$ & 20.57 \\
\hline & Male & 511 & $4.75 \pm 0.05 * *$ & 394 & $29.88 \pm 0.80$ & 22.90 \\
\hline & Female & 456 & $4.47 \pm 0.05^{* *}$ & 356 & $28.44 \pm 0.84$ & 21.59 \\
\hline \multicolumn{2}{|c|}{ Total } & $965^{2}$ & $4.62 \pm 0.03$ & 750 & $29.16 \pm 0.59$ & 22.28 \\
\hline
\end{tabular}

\section{Discussion}

Oestrus rate $(96.45 \%)$ and lambing rate $(90.55 \%)$ determined in this study from primiparous Awassi ewes show good fertility parameters to compare other studies of Awassi sheep (Odabaşığlu, 1985; Gootwine and Goot, 1996; Özbey and Akcan, 2000; Tabbaa et al., 2008). Considering primiparous ewes mentioned to have lower lamb production in the study byGootwine and Goot (1996); the results were satisfying for primiparous Awassi ewes. Most of the studies to determine the reproductive parameters of Awassi sheep were carried out by using exogenous hormone to improve reproductive performance. Few materials were used in these studies to see the efficiency of hormones rather than determine the reproductive performances exactly. Even though hormones 
for oestrus synchronization were used in these studies, parameters such as oestrus and pregnancy rate were found to be 88.8 to $100 \%$ (Uçar et al.,2002; Al-Merestani et al., 1999; Üstüner and Oğan, 2013) and 89.8\% (Üstüner and Oğan, 2013)respectively.Özbey and Akcan (2000)studying 40 Awassi ewes found that oestrus and pregnancy rates were $100 \%$ and $90 \%$ respectively. On the other hand, the great variations observed in fertility rate of rams were strongly influenced by ram age (Talafha and Ababneh 2011).

In natural conditions, Awassi ewes give birth to lambs between December and January (Sabri et al., 2020). The lambing season in the study started in March due to unusual climate conditions.Lambing rate was determined to be $83 \%$ in the study byÖzbey and Akcan (2000) while it was $92 \%$ in another study(Odabaşıŏlu, 1985). Lambing rate was found between $76.38 \%$ and $92.3 \%$ in the studies using exogenous hormones(AlMerestani et al., 1999; Alaçam, 2001). It must be pointed out that most of the similar studies showing reproductive parameters of Awassi were carried out in semi-arid climate by using materials as multiparous ewes.

While twinning rate $(9.08 \%)$ in this study showed similar results to the findings ofTabbaa et al. (2008) andÖzbeyaz et al. (2018); it was lower results than other studies in Turkey (Odabaş1oğlu, 1985; Özbey and Akcan, 2000; Üstüner and Oğan, 2013) and studies using exogenous hormones(Al-Merestani et al., 1999). As for litter size (1.09); although showing similar results to the findings ofTabbaa et al. (2008) and Özbeyaz et al. (2018)and; it was quite lower than other studies (Odabaşığlu, 1985; Özbey and Akcan, 2000).

Because of the fact that birth weight is highly correlated with weaning body weight and preweaning growth rate (Jawasreh et al., 2018; Haile et al., 2019) or yearling weight(Raza et al., 2017); selection of Awassi lambs according to birth weight were reported as contributing factor for body growth and development during weaning period (Ata and Hamed, 2015; Şireli et al., 2015). It was concluded that birth and weaning weight of lambs in this study were higher than other similar studies (Vanlı et al., 1984; Al-Merestani et al., 1999; Said et al., 2000; Zarkawi, 2001; Tabbaa et al., 2008; Üstüner and Oğan, 2013; Haile et al., 2017; Özbeyaz et al., 2018; Sabri et al., 2020). However, it should also be considered that the average pre-weaning period lasted 119 days in this study, which was higher than other studies. There are also some slightly higher birth weight values from half-blood improved Awassi flock (Jawasreh and Khasawneh, 2007), Jordanian sheep breeding stations (Jawasreh et al., 2018) and Awassi flock with 2 ages (Şireli et al., 2015). The average birth weight of lambs from the dams of primiparous purebred or crossed with Turkish and Syrian strains was reported to be $4.21 \mathrm{~kg}$ which was almost the same result as ours (Haile et al., 2017).

There was not any significant relationship between weaning weight and factors of sex, birth type even though a birth weight were found to be affected by sex and type of birth, which was similar to other studies (Zarkawi, 2001; Jawasreh and Khasawneh, 2007; Tabbaa et al., 2008; Üstüner and Oğan, 2013; Şireli et al., 2015; Jawasreh et al., 2018; Özbeyaz et al., 2018). Obtaining higher birth weight of the males than females is due to the facts that ewes carrying male lambs were reported to have a greater number of cotyledons, heavier placental weight, and some differences in hormonal levels (Jawasreh et al., 2009). Contrary to our results; Vanlı et al., (1984) didn't find any relationship between birth weight and sex. Some of the studies reported male lambs to have higher weaning weight than female ones which wasn't consistent to our results (Dikmen et al., 2007; Jawasreh and Khasawneh, 2007; Üstüner and Oğan, 2013; Şireli et al., 2015).

Mortality rate is affected by lamb's weakness and rearing ability of dams (Burfening, 1993). One of the most common problems in sheep breeding was lamb mortality in pre-weaning period rate of which was up to $40 \%$ and caused serious economic losses (Binns et al., 2002). Abdelqader et al., (2017) investigated the lamb mortality rate, which was $18.63 \%$ and its reasons. They mentioned that mortality was the highest prevalence in the first week age of lambs and $63.5 \%$ of total mortality was seen in the first weeks. They found an important relationship between birth weight and lamb mortality especially for the ones weighing less than $2 \mathrm{~kg}$ mortality risk of which was much higher. The mortality rate of Awassi lambs in Central Anatolia was found to be in the range of 10-12\% (Üstüner and Oğan, 2013; Özbeyaz et al., 2018). In this study, it can be said that the stillbirth rate was low for -both single and twin lambs $(0.12 \%$ vs $3.09 \%)$. However, mortality rate in the pre-weaning period was too high to compare with other studies. There wasn't enough capacity in the farm because the construction of newborns and sheep barns hadn't been finished on time. It might have been related to workers' lack of experience of raising Awassi lambs as well. The mortality rate of lambs stated to be highest in those of primiparous dams (Tabbaa et al., 2008). Condition status of ewes at lambing, lamb birth weight, management at birth lead to effect preweaning lamb mortalities (Southey et al., 2001; Hatcher et al., 2010; Üstüner ve Oğan, 2013). Although Üstüner ve Oğan (2013) and Getachew et al., (2015) found survival rate of females till weaning was higher, there was no effect of sex and type of birth on survival rate in this study.

Conclusion

The study showed that primiparous Awassi sheep which normally live in arid and hot climate were not affected negatively by different climates such as colder and steppe. The study proved to be good adaptation capacity of Awassi rams in terms of good reproductive performance despite some management problems which is the reflection of the lamb mortality rates. Considering the good performance of primiparous Awassi sheep, genotypes of Awassi population in Ceylanpinar Agriculture Enterprise can be said to have been preserved very well. 


\section{Acknowledgement}

This study was supported by the TEYDEP Project No: 3090404. This article was submitted oral presentation (abstract) at ICABB in October 2017.

\section{References}

1) Abdelqader A, Irshaid R, Tabbaa Mohammad J, Abuajamieh M, Titi H, Al-Fataftah A, 2017. Factors influencing Awassi lambs survivorship under fields conditions. Livestock Science 199: 1-6.

2) Al-Merestani MR, Zarkawi M, Wardeh M, 1999. Early breeding and pregnancy diagnosis in Syrian Awassi sheep yearlings. Reproduction in Domestic Animals34(5): 413-416.

3) Alaçam E, Köprülü Ş, Salmanoğlu R, Akçaba N, 2001. Kuzey Kıbrısta yetiştirilen ivesi koyunlarında kısa aralıklarla üç kere kuzulatmanın döl verimine etkisi. Livestock Studies 41(1): 35-44

4) Ata M, Hamed H, 2015. Relationship between birth weight and body growth of Awassi lambs during early weaning. Journal of Biology, Agriculture and Healthcare 3: 5-9.

5) Binns SH, Cox IJ, Rizvi S, Green LE, 2002. Risk factors for lamb mortality on UK sheep farms. Preventive Veterinary Medicine 52(3-4): 287-303.

6) Dikmen S, Turkmen I, Ustuner H, Alpay F, Balcı F, Petek M, Ogan M, 2007. Effect of weaning system on lamb growth and commercial milk production of Awassi dairy sheep. Czech Journal of Animal Science 52(3): 70 .

7) Dobson H, Fergani C, Routly J, Smith R, 2012. Effects of stress on reproduction in ewes. Animal Reproduction Science 130(3-4): 135-140.

8) Galal S, Gürsoy O, Shaat I, 2008. Awassi sheep as a genetic resource and efforts for their genetic improvement—A review. Small Ruminant Research 79(2-3): 99-108.

9) Getachew T, Gizaw S, Wurzinger M, Haile A, Rischkowsky B, Okeyo AM, Sölkner J, Meszaros G, 2015. Survival analysis of genetic and non-genetic factors influencing ewe longevity and lamb survival of Ethiopian sheep breeds. Livestock science 176: 22-32.

10) Gootwine E, Goot H, 1996. Lamb and milk production of Awassi and East-Friesian sheep and their crosses under Mediterranean environment. Small Ruminant Research 20(3): 255-260.

11) Haile A, Hilali M, Hassen H, Lobo R, Rischkowsky B, 2019. Estimates of genetic parameters and genetic trends for growth, reproduction, milk production and milk composition traits of Awassi sheep. Animal 13(2): 240-247.

12) Haile A, Hilali M, Hassen H, Rekik M, Lobo RNB, Tibbo M, Mwachro JM, Rischkowsky B, 2017. Evaluation of Awassi Sheep Genotypes for Growth, Milk Production and Milk Composition. Embrapa Caprinos e Ovinos-Artigo em periódico indexado 5: S68-S75.

13) Hatcher S, Atkins K, Safari E, 2010. Lamb survival in Australian Merino sheep: a genetic analysis. Journal of Animal Science 88(10): 3198-3205.

14) Jawasreh K, Ismail ZB, Iya F, Castañeda-Bustos VJ, Valencia-Posadas M, 2018. Genetic parameter estimation for pre-weaning growth traits in Jordan Awassi sheep. Veterinary World 11(2): 254.

15) Jawasreh K, Khasawneh A, 2007. Studies of some economic characteristic on Awassi lambs in Jordan. Egyptian Journal of Sheep and Goat Sciences 2(2): 101-110.

16) Jawasreh KIZ, Awawdeh F, Al-Khasawneh A, Shdaifat B, Al-Shboul H, Al-Hamed B, 2009. The effect of some placental factors in birth weight of Awassi lambs. Research Journal of Agriculture \& Veterinary Sciences4: 5-8.

17) Özbey O, Akcan A, 2000. Akkaraman, Morkaraman ve İvesi koyunlarının yarı-entansif şartlardaki verim performansı I. döl ve süt verim özellikleri. Euroasian Journal of Veterinary Sciences 16(1): 109-120.

18) Özbeyaz C, Bilgiç ÖF, Kocakaya A, Ünal N, 2018. Eskişehir de Yetiştirici Koşullarındaki İvesi Koyunlarında Bazı Özelliklerin İncelenmesi. Livestock Studies 58(1): 1-6.

19) Raza A, Kaleri HA, Kaleri RR, Kaleri A, Bux M, Jalbani MA, Ghulam A, Kumar D, Karim A, 2017. Effect of genetic and environmental factors on the growth performance traits of Pak-Awassi sheep. Pure and Applied Biology 6(2): 532-537.

20) Renaudeau D, Collin A, Yahav S, de Basilio V, Gourdine JL, Collier RJ, 2012. Adaptation to hot climate and strategies to alleviate heat stress in livestock production. Animal 6(5): 707-728.

21) Sabri G, Keskin M, Biçer O, Gündüz Z, Behrem S, 2020. Effects of different lambing season on some reproductive characteristics of ewes and growth performance of lambs in Awassi sheep. Livestock Studies 60(1): 32-36.

22) Said S, Muwalla M, Hanrahan J, Orhan A, 2000. Environmental aspects of early growth traits in Awassi sheep breed. Czech Journal of Animal Science 45(1): 1-5.

23) Şireli HD, Vural ME, Karataş A, Akça N, Koncagül S, Tekel N, 2015. Birth and weaning weights of Awassi lambs raised in the GAP International Agricultural Research and Training Center. Ankara Universitesi Veteriner Fakültesi Dergisi 62(2): 139-145. 
24) Tabbaa M, Alnimer M, Shboul M, Titi H, 2008. Reproductive characteristics of Awassi ewes mated artificially or naturally to Jordanian or Syrian Awassi rams. Animal Reproduction Science 5(1): 23-29.

25) Talafha AQ, Ababneh MM, 2011. Awassi sheep reproduction and milk production. Tropical Animal Health and Production 43(7): 1319-1326.

26) Uçar M, Gündoğan M, Özdemir M, Tekerli M, 2002. Synchronization of oestrus in different sheep breeds by progesterone+ecg and investigation of cholesterol and progesterone levels. Eurasian Journal of Veteriary Sciences 18 (3): 79-85.

27) Üstüner H, Oğan MM, 2013. Main productive performance of Awassi sheep in the Central Anatolian Region of Turkey. Turkish Journal of Veterinary and Animal Sciences, 37(3): 271-276.

28) Vanlı Y, Özsoy M, Emsen H, 1984. İvesi koyunlarının Erzurum çevre şartlarına adaptasyonu ve çeşitli verimleri üzerinde araştırmalar. Doğa Bilim Dergisi 8(3): 302-314.

29) Zarkawi M, 1997. Monitoring the reproductive performance in Awassi ewes using progesterone radioimmunoassay. Small Ruminant Research 26(3): 291-294.

30) Zarkawi M, 2001. Oestrous synchronisation and twinning rate of Syrian Awassi ewes treated with progestagen and PMSG during the breeding season. New Zealand Journal of Agricultural Research 44(2-3): 159-163. 